\title{
OPEN
}

Published online: 20 March 2020

\section{Publisher Correction: Analysis of Copy-Number Variations and Feline Mammary Carcinoma Survival}

José Luis Granados-Soler @ , Kirsten Bornemann-Kolatzki, Julia Beck, Bertram Brenig, Ekkehard Schütz, Daniela Betz, Johannes Junginger, Marion Hewicker-Trautwein, Hugo Murua Escobar \& Ingo Nolte

Correction to: Scientific Reports https://doi.org/10.1038/s41598-020-57942-7, published online 22 January 2020

In the original version of this Article, the author Hugo Murua Escobar was incorrectly indexed. This error has now been corrected.

(c) (i) Open Access This article is licensed under a Creative Commons Attribution 4.0 International License, which permits use, sharing, adaptation, distribution and reproduction in any medium or format, as long as you give appropriate credit to the original author(s) and the source, provide a link to the Creative Commons license, and indicate if changes were made. The images or other third party material in this article are included in the article's Creative Commons license, unless indicated otherwise in a credit line to the material. If material is not included in the article's Creative Commons license and your intended use is not permitted by statutory regulation or exceeds the permitted use, you will need to obtain permission directly from the copyright holder. To view a copy of this license, visit http://creativecommons.org/licenses/by/4.0/.

(C) The Author(s) 2020 